\title{
Gender and Relationship Marketing in Nigerian Securities and Stock Brokerage Firms
}

\author{
Rahim A. Ganiyu ${ }^{1}$, Bolajoko N. Dixon-Ogbechi ${ }^{1} \&$ Salome O. Ighomereho ${ }^{2}$ \\ ${ }^{1}$ Department of Business Administration, University of Lagos, Akoka - Yaba, Lagos, Nigeria \\ ${ }^{2}$ Department of Economics and Business Studies, Redeemer's University, Ogun State, Nigeria \\ Correspondence: Bolajoko N. Dixon-Ogbechi, Department of Business Administration, University of Lagos, \\ Akoka - Yaba, Lagos, Nigeria. E-mail: dixonogbechi@yahoo.com
}

Received: March 25, 2013

Accepted: April 22, 2013 Online Published: May 28, 2013

doi:10.5539/ijms.v5n4p72

URL: http://dx.doi.org/10.5539/ijms.v5n4p72

\begin{abstract}
This paper investigates the role of gender in relationship marketing and the relationship marketing variables that are important in stock brokerage business. A sample of 103 clients of stock brokerage firms operating in Lagos State, Nigeria was examined. The ANOVA result shows that females are better relationship officers while the regression result indicated that gender identity has a significant influence ( $p$-value $=0.025, t=2.274)$ on the success of relationship marketing but it is not a sufficient variable to predict the success of relationship marketing strategy as the R-Square value is low (0.049). In addition, all the variables (trust, communication, commitment, support and cooperation) were found to be important. Therefore, it is recommended that stock brokerage firms should consider females for relationship positions and should also put in place the facilities and internal marketing programmes that are needed for its success.
\end{abstract}

Keywords: Gender, relationship marketing, trust, communication, commitment, support and cooperation, clients, stock brokerage firm

\section{Introduction}

The increasing rate of the incidence of globalization of markets and competition in rapidly developing economies has resulted into a shift from short term sales and transaction orientation to relationship marketing (Berry \& Parasuraman, 1991). Relationship plays an important role in the service industry (Gummenson, 1994). It has been observed that many exchanges, particularly in the service industry are relational in nature (Berry, 1983; Gronroos, 1994; Gummenson, 1994; Sheth \& Parvatiyar, 2000). The purpose of relationship marketing is to acquire and retain customers by providing good quality customer services that can generate repeat purchases (Kotler \& Armstrong, 1999). Relationship marketing activities are very important in the financial service industry because significant amount of money, risk and confidential information are pivotal to financial services (Gilbert \& Choi, 2003; Aaltonen, Markowski \& Kirchner, 2008). It is therefore important that firms focus on strategies that can create long-term relationship and also strive to earn customer trust, loyalty and commitment (Eisinberg \& Bell, 2007).

Relationship marketing has been widely investigated in the literature especially its impact on business performance (Gronroos, 1994; Palmatier, Dant, Grewal \& Evans, 2006). The empirical studies in relationship marketing have focused on investigating the associations among the relationship marketing variables (Morgan \& Hunt 1994; Gabbarino \& Johnson, 1999; Sirdeshmukh, Singh \& Sabol, 2002); the relative importance of relationship marketing variables (Dixon-Ogbechi, Haran \& Aiyeku, 2009; Dixon-Ogbechi, Aiyeku, Haran \& Adekoya, 2011) and customers' perception of relationship marketing activities of firms (Verhoef, 2003; Chao, 2008; Dixon-Ogbechi, Haran \& Aiyeku, 2010). However, few empirical investigations have been conducted to explore gender issues in relationship marketing (Bristor \& Fischer, 1993, Kara \& Constanza, 2001). This paper attempts to fill this gap in the literature by examining if females are better than males in building and sustaining customer relationship. It has also been noted that the differences in behaviour between males and females as well as the hierarchical implications of those differences are evident (Costa, 1994). Gender identity therefore may be a potential individual variable that could influence the extent to which a relationship marketing program or effort will be successful (Kara \& Constanza, 2001). 


\subsection{Objectives of the Paper}

The objectives of this paper are to:

Investigate if females are more efficient in each of the relationship marketing constructs than their male counterparts.

Examine if gender identity has any influence on the success of a relationship marketing strategy.

Ascertain the relationship marketing variables that are important in stock brokerage business.

\subsection{Research Hypotheses}

Ho1: There are no significant differences between females and males with respect to efficiency in each of the relationship marketing constructs.

Ho2: Gender identity has no significant influence on the success of a relationship marketing strategy.

\section{Literature Review}

\subsection{Relationship Marketing}

In spite of the fact that relationship marketing has been widely investigated in marketing literature, majority of scholars and practitioners agree that it is not an easy concept to formulate and practice (Egan, 2004). It consists of several activities and therefore could mean different things to different people (Palmer \& David, 1994; Too, Soulchen \& Thirkell, 2001). Notwithstanding, it is usually referred to as a process of attracting, maintaining and enhancing relationships with customers and stakeholders (and where/when necessary, terminate them) at a profit, so as to achieve the objectives of the parties involved (Gronroos, 1994; Kotler \& Armstrong, 1999; Adamson, Chan \& Handford, 2003; Zineldin \& Philipson, 2007; Das, 2009). Morgan \& Hunt (1994) described relationship marketing as inter-firm and intra-firm relationships which refer to all marketing activities directed toward establishing, developing, and maintaining successful relational exchanges. Berry (1995) describes relationship marketing as all the marketing activities directed towards establishing, developing and maintaining successful relational exchanges in order to meet the objectives of both parties involved. It includes all the marketing activities designed to establish, develop, maintain and sustain a successful relational transaction with a view of acquiring and retaining customers who can contribute to long-term organizational profitability (Dixon-Ogbechi et al., 2010).

Despite the recognition of relationship marketing as an important topic in marketing, the scope and future direction of the discipline are diverse and disputed (Payne, 1997). Conventional relationship marketing has focused on long-term commitment and affect-laden relationships in both business-to-business context and also firm to consumer settings. It has also assumed to some extent that relationships are always desirable. However, it is widely acknowledged by scholars and practitioners that relationships are not always desired by customers in all situation (Blois, 1996) and that firm's efforts to maintain such a relationship may lead to customer irritation and costly for the firm in terms of money invested in undesired relationships. Nevertheless, scholars concur that relationship marketing offers a succor and solution to organizations in enhancing customer-firm relationship in this era of ever-increasing competition (Rosenburg \& Cant, 2003). Since the conception of relationship marketing by Berry in 1983, it has increasingly attracted the attention of researchers and practitioners. Fournier, Dobscha \& Mick (1998) noted that relationship marketing is a potent strategy in theory but difficult in practice, due to the fact that firms are attempting relational initiatives with all customers, without recourse to the customers' relational orientations. These authors' claims that customers who prefer discrete transactions feel uncomfortable and manipulated by firms that attempt to engage them in relationships. For a relationship marketing programme to be successful, the customer must be prone to engage in a relationship, which means that he/she must have a relational orientation (Blois, 1996). When a firm is not targeting the right customers, they will be wasting money, efforts and time on undesired relationships. Hence, there is need to segment the customers and determine which of the segment will be profitable in the long run (Garbarino \& Johnson, 1999).

\subsubsection{Relationship Marketing Constructs}

Extant literature on relationship marketing shows that there is no consensus regarding the identification of variables influencing longevity of customer-service providers' relationship. Studies in relationship marketing have revealed various relationship marketing variables such as dependence, trust, opportunism, internal marketing, satisfaction, communication, relationship commitment, shared value, support and cooperation. The six factors cited most often are trust, commitment, cooperation, internal marketing, shared value and communication (Morgan \& Hunt, 1994; Egan, 2001; Ndubuisi \& Chan, 2005). Those that have been found to be more important are relationship satisfaction, trust and relationship commitment (Tseng, 2005). A study 
conducted by (Dixon-Ogbechi et al., 2009, 2011) revealed that trust, relationship commitment, communication, internal marketing, support and cooperation were the most important elements of relationship marketing. In this paper, four of these relationship marketing variables trust, commitment, communication and support and cooperation were examined. Internal marketing is left out because the clients may not have sufficient knowledge of internal marketing issues or techniques adopted by business organization to motivate and empower employees at all functions and levels to consistently deliver a positive customer experience (Dixon-Ogbechi et al., 2009).

Trust is the reliability of an organization's employees and beliefs in their willingness to perform their duties (Simpson \& Mayo, 1997). It is an experience of mutual honesty and confidence that includes few negative surprises and is established on the basis of similar values (Olotu, Maclayton \& Opara, 2010). Relationship commitment is the psychological attachment of customers to an organization (Dixon-Ogbechi et al., 2009). Mohr, Fisher \& Nevin (1996) considered relationship commitment to be the extent to which a firm's perception contributes to maintaining their cooperative relationships while communication is the exchange of meaningful and timely information between firms and their customers. Support and Cooperation comprise all mutually beneficial activities embarked upon by both the organization and its customers (Dixon-Ogbechi et al., 2009).

\subsection{Gender and Relationship Marketing}

The extent to which gender issues, and in particular gender stereotyping, permeate the relationship marketing activities is a matter of concern in a globalized economy. Gender stereotyping is the generalization of what it means to be male or female, the roles that are considered appropriate to women and men based on traditional generalizations regarding gender, and the characterizations that make male or female (Stranger \& Lange, 1994). According to Gilligan (1982) women are more "relationship focused" than men. She discussed how this tendency develops from a psychoanalytic viewpoint. According to her the childhood of girls differs fundamentally from that of boys. Girls identify personally with their mothers who are care-givers and always around. Boys are encouraged to identify with their fathers who are not available as much. This difference between "positional identification" of boys and "personal identification" of girls is the key to what makes women more open to relationship formation (Bristor \& Fischer, 1993). Fournier (1998) used female respondents exclusively in her study of brand relationships. Her conclusion was in tandem with the findings of previous research, that women exhibit more and stronger interpersonal relationships and brand involvement than men ( for instance, Gainer, 1993; Kara \& Constanza, 2001).

Furthermore, Kara \& Constanza (2001) proposed that female customers are more relational than males and will therefore be more likely to engage in relational market behaviour with firms. In general, the research looking at gender has shown that female customers more often than males define themselves in terms of their relationships and are more relational oriented. However, Gilligan (1982) suggested that there will be some form of variation within groups or across cultures. Therefore, the interpretations should not necessarily be considered to represent a generalization about either sex. Aaltonen et al., (2008) investigated the extent to which key demographic variables moderate relationships in financial services. Although there was no conclusive evidence of moderating effects of the demographic variables studied, they reported some potential evidence of such effects that will require further research to confirm. The authors suggested that tailoring relationship strategies towards gender, income level, and age may not necessarily be pivotal and that attention may be better directed to other areas like personality and psychological factors of human being.

However, the focus of this paper is on female and male employees serving as relationship officers. The fundamental question addressed by this paper is to ascertain if female relationship officers are better in relationship marketing activities than male relationship officers? In most regions of the world, labour force participation rates of men are higher than those of women but women are more represented in service occupations, clerical jobs, sales, professional and technical jobs particularly in developing countries while men are highly over-represented in production jobs as well as in higher-paid administrative and managerial jobs (World Bank, 2001). Blau, Simpson \& Anderson (1998) noted that women, especially in developing countries, are confronted by formidable constraints that block their opportunities due to perceive traditional role of women in society and the prevalent misconception that women's reproductive and domestic responsibilities constitute their main role. The authors further posits that the imbalance in men/women employment status began to change in the 1990s and that although many of the broad outlines of these occupational differences between men and women remain, the disparities have been significantly reduced and so, quite a number of women have moved into a variety of traditionally male jobs throughout the occupational spectrum. For instance, in most advisor-client relationship such as stock brokerage firms, there are as many female employees as there are male employees (Sue, 2012). 


\section{Research Methodology and Method}

\subsection{Research Design}

To achieve the research objectives, the researchers adopted ex-post facto research design using quantitative research approach.

\subsection{Population and Sample Size Selection}

The population of the study is made up of all the clients of securities and stock brokerage firms operating in Lagos State that are listed with the Securities and Exchange Commission. Out of the one hundred and ninety eight (198) firms, ten (10) were selected (Zenith Securities Ltd, ESL Securities Ltd, Meristem Securities Ltd, Diamond Securities Ltd, Afribank Securities Ltd, Integrated Trust and Investment Ltd, Readings Investment Ltd, Resort Securities Ltd, Pivot Trust and Investment Ltd and Lighthouse Asset Management Ltd) using simple random sampling via balloting. Volunteer sampling technique was then used to survey one hundred and fifty (150) clients of the selected firms (15 clients per firm). This type of sampling occurs when people volunteer their services for the study. This became necessary because the list of the clients was not made available and the clients of stockbrokerage firms do not visit the firms regularly. When they visit, they are usually more concerned with the issues that they want to address. Some of them deliberately refused to collect the questionnaires with the excuse that they are in a hurry and they will not be visiting within the period of one month when the questionnaires will be retrieved. The study was carried out between 15th January to 15th February, 2013. Based on these limitations, the clients that accepted to collect the questionnaires were sampled.

\subsection{Instrumentation}

In this study, a self-completion questionnaire with closed ended items was designed by the authors. Given that most of the items in the questionnaire measured respondents perception, a five-point Likert rating scales, ranging from strongly agree (5), agree (4), fairly agree (3), disagree (2) to strongly disagree (1) and from very important (5), important (4), fairly important (3), unimportant (2) to very unimportant (1) was adapted. The questionnaire consists of three (3) sections and they cover respondents' evaluation of relationship marketing variables with respect to their relationship officers as well as evaluation of gender identity and relationship success (33 items), respondents' rating of relationship marketing variables (10 items) and items to identify respondents' demographics ( 7 items). The instrument was validated through content analysis by using a senior academic staff in the Department of Business Administration, University of Lagos. Reliability was determined using Cronbach Alpha. The Cronbach Alpha recorded for section A and B (0.9, 0.8 respectively) were under acceptable range $\alpha \geq$ 0.7 (Girden, 2001). One hundred and fifty (150) copies of questionnaires were administered but one hundred and three (103) (68.7\%) were retrieved and used for the analysis.

\section{Results and Discussion}

The data collected were analyzed using Statistical Package for Social Sciences (SPSS-Version 17).

\subsection{Demographic Information}

Majority of the respondents are males $(60.2 \%)$ while $(39.8 \%)$ are females. The age distributions are 20 years and below $(2.9 \%), 21-30$ years $(18.4 \%), 31-40$ years $(36.9 \%), 41-50$ years $(19.4 \%), 50$ years and above $(22.3 \%)$. Most of them (65\%) are married, $(24.3 \%)$ are single, $(5.8 \%)$ are divorced while $(4.9 \%)$ are separated. (95.1\%) are educated up to tertiary level, $(3.9 \%)$ have secondary education while (1\%) has no education. Majority of them $(50.5 \%)$ are working in the private sector, $(25.2 \%)$ are self-employed, $(18.4 \%)$ are in the public sector while $(5.8 \%)$ are students. Their monthly income level are below N500, $000(53.4 \%)$, N501, 000-N1, 000,000 $(25.2 \%), \mathrm{N} 1,001,000-\mathrm{N} 2,000,000(20.4 \%)$ while N2, 000,000 and above (1\%). Majority of the relationship officers (54.4\%) are females while (45.6\%) are males.

\subsection{Gender Differences in Each of the Relationship Marketing Constructs}

In order to test if there are significant gender differences in each of the relationship marketing constructs, Analysis of Variance (ANOVA) test was conducted. The result is shown in table 1: 
Table 1. ANOVA result on gender differences in each of the relationship marketing constructs

\begin{tabular}{|c|c|c|c|c|c|c|}
\hline & & Sum of Squares & Df & Mean Square & $\mathrm{F}$ & Sig. \\
\hline \multirow[t]{3}{*}{ Trust } & Between Groups & 7.374 & 1 & 7.374 & 8.582 & .004 \\
\hline & Within Groups & 86.786 & 101 & .859 & & \\
\hline & Total & 94.160 & 102 & & & \\
\hline \multirow[t]{3}{*}{ Commitment } & Between Groups & 9.689 & 1 & 9.689 & 8.968 & .003 \\
\hline & Within Groups & 109.115 & 101 & 1.080 & & \\
\hline & Total & 118.804 & 102 & & & \\
\hline \multirow[t]{3}{*}{ Communication } & Between Groups & 7.909 & 1 & 7.909 & 10.023 & .002 \\
\hline & Within Groups & 79.699 & 101 & .789 & & \\
\hline & Total & 87.608 & 102 & & & \\
\hline \multirow{3}{*}{$\begin{array}{l}\text { Support } \\
\text { Cooperation }\end{array}$} & and Between Groups & 10.576 & 1 & 10.576 & 13.017 & .000 \\
\hline & Within Groups & 82.061 & 101 & .812 & & \\
\hline & Total & 92.637 & 102 & & & \\
\hline
\end{tabular}

Source: Authors Fieldwork, 2013.

Table 1 shows that gender differences in each of the relationship marketing variables are significant (all the $\mathrm{p}$-values are less than 0.05). In addition, all the computed $\mathrm{F}$ values are greater than the table value of 4.00 (Ftab $0.05,1,101)$. However, the ANOVA table only determines if there are significance differences between two or more groups, it does not indicate the group that is different. To find out the nature of the differences, the group statistics was computed.

Table 2. Group statistics result on gender differences in each of the relationship marketing constructs

\begin{tabular}{llllll}
\hline & $\begin{array}{l}\text { Gender of } \\
\text { Relationship } \\
\end{array}$ & & & & \\
& Officer & $\mathrm{N}$ & Mean & Std. Deviation & Std. Error Mean \\
\hline Trust & Male & 47 & 3.1513 & 1.01371 & .14786 \\
& Female & 56 & 3.6885 & .84763 & .11327 \\
Commitment & Male & 47 & 3.2057 & 1.03514 & .15099 \\
& Female & 56 & 3.8214 & 1.04295 & .13937 \\
Communication & Male & 47 & 3.1733 & 1.00837 & .14709 \\
& Female & 56 & 3.7296 & .77372 & .10339 \\
Support and & Male & 47 & 3.1915 & .96995 & .14148 \\
Cooperation & Female & 56 & 3.8348 & .83975 & .11222 \\
\hline
\end{tabular}

Source: Authors' Fieldwork, 2013.

Table 2 indicates that out of the 103 respondents studied, 47 of them have male relationship officers while 56 have female relationship officers. Analysis of the means shows that in all the constructs, the female relationship officers have a higher mean and so are better than their male counterparts. Therefore, we reject the null hypothesis that there are no significant differences between females and males with respect to efficiency in each of the relationship marketing constructs.

\subsection{The Influence of Gender Identity on the Success of Relationship Marketing Strategy}

To determine the influence of gender identity on the success of relationship marketing, regression analysis was carried out. The results of the regression analysis are depicted in tables 3, 4 and 5: 
Table 3. Model summary result on the influence of gender identity on the success of relationship marketing strategy

\begin{tabular}{llllll}
\hline Model & R & R Square & Square & R Std. Error of the \\
& Sqtimate & Durbin-Watson \\
\hline 1 & $.221 \mathrm{a}$ & .049 & .039 & .66217 & 1.474 \\
a. Predictors: (Constant), Gender of Relationship Officer \\
b. Dependent Variable: Success of Relationship Marketing Strategy
\end{tabular}

Table 3 shows the model summary of the regression. The R-Square value is 0.049 . This indicates that gender identity only explains $4.9 \%$ of the variance in relationship marketing success. This may be attributed to the fact that there are several other factors that could influence the success of the strategy. For instance, Blois (1996) and Fournier et al., (1998) emphasized that the relational orientation of customers is important to the success of relationship marketing. Other factors may include internal marketing activities, availability and functional communication infrastructure and motivation. This implies that the proposition of Kara \& Constanza (2001) that gender identity may be a potential individual variable that could influence the extent to which a relationship marketing program or effort will be successful is not justified in stock brokerage business in Nigeria.

Table 4. ANOVA result on the influence of gender identity on the success of relationship marketing strategy

\begin{tabular}{lllllll}
\hline Model & & Sum of Squares & df & Mean Square & F & Sig. \\
\hline 1 & Regression & 2.268 & 1 & 2.268 & 5.173 & $.025 \mathrm{a}$ \\
& Residual & 44.285 & 101 & .438 & & \\
& Total & 46.553 & 102 & & &
\end{tabular}

a. Predictors: (Constant), Gender of Relationship Officer

b. Dependent Variable: Success of Relationship Marketing Strategy

Table 4 indicates the significance of the model. The p-value $(0.025)$ is less than 0.05 and so the model is significant.

Table 5. Impact of gender identity on the success of relationship marketing strategy

\begin{tabular}{lllllll}
\hline & & \multicolumn{4}{c}{ Standardized } \\
Model & & B & Std. Error & Beta & T & Sig. \\
\cline { 2 - 5 } 1 & (Constant) & 1.830 & .212 & & 8.611 & .000 \\
& Gender of Relationship Officer & .298 & .131 & .221 & 2.274 & .025 \\
\hline
\end{tabular}

Dependent Variable: Success of Relationship Marketing Strategy

Source: Authors' Fieldwork, 2013.

Table 5 shows the t-value (2.274) and the p-value (0.025). The null hypothesis is rejected when t-value is greater than 2 and the p-value is less than 0.05 (Girden, 2001). Since the result satisfies these conditions, the hypothesis that gender identity has no significant influence on the success of a relationship marketing strategy is rejected. This implies that the gender of a relationship officer is significant in stock brokerage business but it is not a sufficient factor. 


\subsection{Importance of Relationship Marketing Variables}

Table 6. Descriptive statistics result on the importance of relationship marketing variables

\begin{tabular}{llllll}
\hline & $\mathrm{N}$ & Minimum & Maximum & Mean & Std. Deviation \\
\hline Trust & 103 & 1.00 & 5.00 & 4.6529 & .39796 \\
Communication & 103 & 1.00 & 5.00 & 4.5825 & .52439 \\
Commitment & 103 & 1.00 & 5.00 & 4.5146 & .55773 \\
Support and Cooperation & 103 & 1.00 & 5.00 & 4.3689 & .76684 \\
Valid N (listwise) & 103 & & & & \\
\hline
\end{tabular}

Source: Authors' Fieldwork, 2013.

Table 6 indicates the relative importance of the relationship marketing constructs with respect to stock brokerage firms. The result shows that all the constructs are important to the clients (mean values > 4) but trust (reliability, integrity, keeping promises and transparency) is the most important followed by communication (communicating regularly and attentiveness); commitment (relationship commitment and professionalism), support and cooperation (cooperation and helping behaviour). This result is in consonance with the findings of Tseng (2005), Dixon-Ogbechi et al., $(2009,2011)$ except for communication that is more important than commitment in this paper. Stockbrokerage firms therefore, needs to recognize the business principle that winning and keeping customers and clients requires more than rendering financial services and sending organizational sales personnel to close sales. They must devote time to build relationships with their customers in order to gain repeat patronage and enhance their profitability (Dixon-Ogbechi et al., 2009).

\section{Conclusion}

In this era of intense competition in the business environment, organizations ability to create, maintain and enhance long-term customer relationship is a basis for achieving and sustaining competitive advantage (Berry, 1983). Business organizations have recognized the importance of interaction and mutual collaboration with customers through relationship marketing activities. This scenario has extended the domain of relationship marketing into many areas of marketing and strategic decisions (Parvatiyar \& Jagadish, 1997). In fact, relationship marketing is conceived as one of the areas with most expression in the field of marketing, recognized not only by academics but also by practitioners. Its recent popularity and prominence is facilitated by the convergence of several other paradigms of marketing and by corporate initiatives programs that are developed around the theme of cooperation and collaboration among organizational units and its stakeholders (Carlos, 2011). Relationship marketing is therefore recognized as a strategic tool for customer retention and source of differential advantage (Reicheld \& Sasser, 1990). However, with intense competition and loss of investors' confidence in stock market, stock brokerage firms need to be more concerned about relationship marketing so as to encourage and build investors interest and confidence (Eboh, 2011). They need to build trust and renew investors' confidence which is at the lowest ebb with the aftermath of stock market crash (Oladipupo, 2010). They should equally make concerted effort to put in place effective and collaborative communication systems which will generate volitional compliance between partners and bolster relationship performance. This will increase marketing productivity in terms of efficiency and effectiveness; efficiency is enhanced through different consumer values being recognized and individual's needs being better addressed and effectiveness through greater customer retention and higher profits. (Sheth \& Parvatiyar, 2000).

This study contributes to existing knowledge by revealing the key relationship marketing constructs in stock brokerage business (trust, commitment, communication, and support and cooperation). It also revealed that gender identity has a significant influence on the success of relationship marketing programme and that female employees are more efficient in relationship marketing activities than males. Consequently, the study recommends that stock brokerage firms should consider females for relationship positions and also put in place necessary facilities and internal marketing programmes to ensure that their relationship marketing activities achieve the desired results.

\section{Acknowledgements}

We appreciate all the respondents for creating time to fill the questionnaires and the staff of the selected firms that assisted us to persuade the clients to fill the questionnaires despite their busy schedules. 


\section{References}

Aaltonen, P. G., Markowski, E. P., \& Kirchner, T. A. (2008). Relationship Marketing Management and Satisfaction/Loyalty: Effects of Gender, Age and Income. European Journal of Management, 8(3).

Adamson, I., Chan, K. M., \& Handford, D. (2003). Relationship Marketing: Customer Commitment and Trust as Strategy for the Smaller Hong Kong Corporate Banking Sector. International Journal of Bank Marketing, 21(6/7), 347-358. http://dx.doi.org/10.1108/02652320310498492

Berry, L. L. (1983). Relationship Marketing. In Berry, L. L., Shostack G. L., \& Upah, G. D. (Eds.), Emerging Perspectives on Services Marketing (pp. 25-28). Utah: American Marketing Association.

Berry, L. L. (1995). Relationship Marketing of Services - Growing Interest, Emerging Perspective. Journal of the Academy of Marketing Science, 23(4), 236-45. http://dx.doi.org/10.1177/009207039502300402

Berry, L. L., \& Parasuraman, A. (1991). Marketing Services: Competing through Quality. New York, NY: Free Press.

Bickert, J. (1992). The Database Revolution. Target Marketing, May, 14-18.

Blau, F., Simpson, P. A., \& Anderson, D. (1998). Continuing Progress? Trends in Occupational Segregation in the United States over the 1970s and 1980's. Management Review, 21, 332-352.

Blois, K. J. (1996). Relationship Marketing in Organizational Markets: When is it Appropriate? Journal of Marketing Management, 12, 161-173. http://dx.doi.org/10.1080/0267257X.1996.9964406

Bristor, J. M., \& Fischer, E. (1993). Feminist Through: Implications for Consumer Research. Journal of Consumer Research, 19, 518-535. http://dx.doi.org/10.1086/209320

Carlos, B. (2011). Relationship marketing: old wine in a new bottle? Innovative Marketing, 7(1), 66-77.

Chao, P. (2008). Exploring the Nature of the Relationships between Service Quality and Customer Loyalty: An Attribute-Level Analysis. The Service Industries Journal, 28(1), 95-116.

Claessens, S. (2009). Competition in the Financial Sector: Overview of Competition Policies. IMF Working Paper. Retrieved Dec 2, 2013, from http://www.imf.org/external/pubs/ft/wp/2009/wp0945.pdfSimilar

Costa, J. A. (1994). Gender Issues and Consumer Behaviour. California: Sage Publications, Inc.

Das, K. (2009). Relationship Marketing Research (1994-2006): An Academic Literature Review andClassification. Marketing Intelligence and Planning, 27(3), 326-363. http://dx.doi.org/10.1108/02634500910955236

Dixon-Ogbechi, B. N., Aiyeku, J. F., Haran, E., \& Adekoya, A. G. (2011). Determination of the Strategic Process Model. International Symposium on the Analytic Hierarchy Process. Sorrento, Italy - Proceedings. ISAHP 069: 1-6.

Dixon-Ogbechi, B. N., Haran, E. M., \& Aiyeku, J. (2009). Application of the Analytic Hierarchy Process in Determining Relative Importance of Relationship Marketing Variables for Companies in the Nigerian Food and Beverage Industry. International Symposium on the Analytic Hierarchy Process (ISAHP) for Complex Decision Making, Pittsburgh, USA - Proceedings, No. 21, 1-15.

Dixon-Ogbechi, B. N., Haran, E. M., \& Aiyeku, J. (2010). Customers' Perception of Relationship Marketing as a Strategic Tool in the Nigerian Food and Beverages Industry. Journal of Management Policy and Practice, 11(5), 124-132.

Eboh, M. (2011). Capital Market: Declining Investors' Confidence Worries SEC. Retrieved Dec 2, 2013, from http://www.vanguardngr.com/.../capital-market-declining-inv

Egan, J. (2001). Relationship Marketing. London: Pearson Education.

Egan, J. (2004). Relationship Marketing. Exploring Relational Strategies in Marketing (2nd ed.). England: Prentice Hall.

Eisinberg, A. B., \& Bell, S. J. (2007). Maintaining Customer Relationships in High Credence Services. Journal of Service Marketing, 21(1), 253-262.

Fournier, S. (1998). Consumers and Their Brands: Developing Relationship Theory in Consumer Research. Journal of Consumer Research, 24(4), 343-373. http://dx.doi.org/10.1086/209515

Fournier, S., Dobscha, S., \& Mick, D. G. (1998). Preventing the Premature Death of Relationship Marketing. Harvard Business Review, 42-51. 
Gainer, B. (1993). An Empirical Investigation of the Role of Involvement with a Gendered Product. Psychology and Marketing, 10(4), 265-283. http://dx.doi.org/10.1002/mgr.4220100403

Garbarino, E., \& Johnson, M. S. (1999). The Different Roles of Satisfaction, Trust, and Commitment in Customer Relationships. Journal of Marketing, 63, April, 70-87.

Gilbert, D. C., \& Choi, K. C. (2003). Relationship Marketing Practice in Relation to Different Bank Ownerships: A Study of Banks in Hong-Kong. International Journal of Bank Marketing, 21(3), 137-146. http://dx.doi.org/10.1108/02652320310469511

Gilligan, C. (1982). Why Should a Woman be More Like a Man? Psychology Today, June, 68-75.

Girden, E. R. (2001). Evaluating Research Articles (2nd ed.). London: Sage.

Gronroos, C. (1994). From Marketing Mix to Relationship Marketing: Towards a Paradigm Shift in Marketing. Management Decision, 32(2), 4-20. http://dx.doi.org/10.1108/00251749410054774

Gummesson, E. (1994). Making Relationship Marketing Operational. International Journal of Service Industry Management, 5(5), 5-20. http://dx.doi.org/10.1108/09564239410074349

Kara, A. A., \& Constanza, B. (2001). Relationship Marketing, Gender, and Culture: Implications for Consumer Behaviour. In Mary C. G., \& Joan M. L. (Eds.), Advances in Consumer Research (vol. 28, pp. 100-105). Association for Consumer Research.

Kotler, P., \& Armstrong, G. (1999). Principles of Marketing (8th ed.). Upper Saddle River, New Jersey: Prentice Hall.

Mohr, J. J., Fisher, R. J., \& Nevin, J. R. (1996). Collaborative Communication in Inter-firm Relationships: Moderating Effects of Integration and Control. Journal of Marketing, 60(1), 103-115. http://dx.doi.org/10.2307/1251844

Morgan, R. M., \& Hunt, S. D. (1994). The Commitment-Trust Theory of Relationship Marketing. Journal of Marketing, 58(3), 20-38. http://dx.doi.org/10.2307/1252308

Ndubuisi, N. O., \& Chan, K. W. (2005). Factorial and Discriminant Analyses of the Underpinnings of Relationship Marketing and Customer Satisfaction. International Journal of Bank Marketing, 23(3), 542-547. http://dx.doi.org/10.1108/02652320510629908

Nevin, J. R. (1995). Relationship Marketing and Distribution Channels: Exploring Fundamental Issues. Journal of the Academy of Marketing Sciences, 13, 135-156.

Oladipupo, O. F. (2010). The Crash of Nigerian Capital Market: Explanations Beyond the Global Meltdown. International Business Management, 4(2), 35-40.

Olotu, A. O., Maclayton, D. W., \& Opara, B. C. (2010). An Empirical Study of Relationship Marketing Orientation and Bank Performance. Research Journal of International Studies, 16(September), 47-57.

Palmatier, R. W., Dant, R. P., Grewal, D., \& Evans, K. R. (2006). Factors Influencing the Effectiveness of Relationship Marketing: A Meta-Analysis. Journal of Marketing, 70(4), 136-153. http://dx.doi.org/10.1509/jmkg.70.4.136

Palmer, A., \& David, B. (1994). Buyer-Seller Relationships: A Conceptual Model and Empirical Investigation. Journal of Marketing Management, 10(6), 495-512. http://dx.doi.org/10.1080/0267257X.1994.9964296

Parvatiyar, A., \& Jagdish, N. S. (1997). Paradigm Shift in Inter-firm Marketing Relationships. Research in Marketing, 13, 233-255.

Payne, A. (1997). Relationship Marketing: The U.K. Perspective. ANZMEC ' 97.

Reicheld, F. F., \& Sasser, W. E. Jnr. (1990). Zero Defections: Quality Comes to Services. Harvard Business Review, 68(September-October), 105-111.

Rosenberg, R. S., \& Cant, M. (2003). Public Relations: South African Perspective. South Africa: Heineman.

Sheth, J. N., \& Parvatiyar, A. (2000). Handbook of Relationship Marketing. Thousand Oaks, CA: Sage Publications.

Simpson, J. T., \& Mayo, D. T. (1997). Relationship Management: A Call for Fewer Influence Attempts? Journal of Business Research, 39(7), 209-18. http://dx.doi.org/10.1016/50148- 2963(96)00205-6

Sirdeshmukh, D., Singh, J., \& Sabol, B. (2002). Consumer Trust, Value, and Loyalty in Relational Exchanges. Journal of Marketing, 66(1), 15-37. http://dx.doi.org/10.1509/jmkg.66.1.15.18449 
Stranger, C., \& Lange, I. E. (1994). Mental Representation of Social Groups: Advances in Understanding Stereotypes and Stereotyping. Advances in Experimental Social Psychology, 26, 354-416.

Sue, T. C. (2012). Role Revolution: Gender in the Advisor-Client Relationship. Global market intelligence. Retrieved from http://isharesblog.com/blog/2012/05/02/role-revolution-gender-inthe-advisor-client-relationship/

Too, H. Y., Soulchen, A. L., \& Thirkell, P. C. (2001). Relationship Marketing and Customer Loyalty in a Retail Setting: A Dyadic Exploration. Journal of Marketing Management, 17, 287-319.

Tseng, Y. (2005). How Can Marketing Tactics Build Behavioural Loyalty? The Business Review, 3(2), 298-302.

Verhoef, P. C. (2003). Understanding the Effect of Customer Relationship Management Efforts on Customer Retention and Customer Share Development. Journal of Marketing, 30-45. http://dx.doi.org/10.1509/jmkg.67.4.30.18685

World Bank. (2001). Engendering Development through Gender Equality in Rights, Resources and Voice. Washington.

Zineldin, M., \& Philipson, S. (2007). Kotler and Borden are not Dead: Myth of Relationship Marketing and Truth of the 4Ps. Journal of Consumer Marketing, 24(4), 229-241. http://dx.doi.org/10.1108/07363760710756011

\section{Copyrights}

Copyright for this article is retained by the author(s), with first publication rights granted to the journal.

This is an open-access article distributed under the terms and conditions of the Creative Commons Attribution license (http://creativecommons.org/licenses/by/3.0/). 